\title{
STANJE I IZAZOVI GOSPODARENJA PRIVATNIIM ŠUMAMA U HRVATSKOJ U POSTOJEĆIM EKOLOŠKIM I SOCIOLOŠKIM OKOLNOSTIMA
}

\author{
STATUS AND CHALLENGES OF SMALL-SCALE PRIVATE \\ FOREST MANAGEMENT IN ACTUAL ECOLOGICAL AND \\ SOCIAL CIRCUMSTANCES - CROATIA CASE STUDY
}

\author{
Krunoslav TESLAK1, Marijana ŽUNIĆ2 ${ }^{\text {, Karlo BELJAN }}$, Jura ČAVLOVIĆ4
}

\section{SAŽETAK}

Gospodarenje šumama u Hrvatskoj je pretežito koncentrirano i usmjereno prema šumama u državnom vlasništvu, koje je stoga obilježeno stalnošću i dosljednošću planiranja i provedbe postupaka gospodarenja, te se provode načela održivog gospodarenja na svim razinama. Nasuprot tomu, privatne šume su uslijed povijesnih okolnosti te male zastupljenosti i usitnjenosti bile značajno zapostavljene sve do nedavno. Stoga je cilj ovog rada analizirati i prikazati postojeća obilježja privatnih šuma, šumoposjeda i šumoposjednika, kao i okolnosti gospodarenja tj. institucionalnog i regulatornog okvira u kojemu se ono odvija.

Površinski udio od 24\% i drvnu zalihu od $156 \mathrm{~m}^{3} /$ ha uz bogatstvo vrstama i razvojnim stadijima čini privatne šume vrlo vrijednim prirodnim resursom. Iako je posljednjih godina ostvaren značajni napredak, neriješeni imovinskopravni odnosi, nedorečen Zakonski okvir te nepovoljna sociološka obilježja šumoposjednika (velik udio starije populacije i niska razina obrazovanja) otežavaju daljnje unaprjeđenje gospodarenja.

Za razliku od katastarske baze podataka anketni upitnici vrijedan su izvor informacija o obilježjima šumoposjeda i šumoposjednika, poglavito za znanstvena istraživanja. Prosječna obilježja šumoposjednika prikazana u ovome radu (prosječna dob od 60 godina i razmjerno niska razina obrazovanja) nisu ohrabrujuća. Međutim, ipak bi donošenje šumarskih politika trebalo biti utemeljeno na spoznajama o tipovima i stavovima šumoposjednika, posebno onih koji su spremni aktivno se baviti šumarstvom. Pri tome jasno treba razdvojiti šumoposjednika koji gospodari šumom i stavlja šumske proizvode na tržište (šumoposjednici upisani u Upisnik) i vlasnika sitnih šumskih čestica koji šumu u većoj ili manjoj mjeri koriste za vlastite potrebe.

Poseban problem planiranja uravnoteženog i održivog gospodarenja je postojeći usporedni sustav planiranja i gospodarenja razdvojen prema vlasništvu. Objedinjavanjem svih javnih nadležnosti nad šumama u jedinstvenu instituciju uz ustrojavanje većeg broja šumskogospodarskih područja omogućilo bi ispunjavanje zahtjeva potrajnog gospodarenja i održivosti šuma uz ostvarivanje dugoročnih javnih interesa.

Za učinkovitu i potpunu uspostavu sveobuhvatnog i potrajnog gospodarenja šumama potrebno je od strane svih dionika usvajanje spoznaja o specifičnostima gospodarenja privatnim šumama, uključujući i primjenu dobivenih rezultata provedenih znanstvenih istraživanja.

KLJUČNE RIJEČI: šumoposjednici, šumoposjed, socio-demografska obilježja, struktura privatnih šuma, raznodobno gospodarenje, potrajno gospodarenje

\footnotetext{
1Doc. dr. sc. Krunoslav Teslak, e-mail: kteslak@sumfak.hr ${ }^{2}$ Marijana Žunić, mag. ing. silv., e-mail: mzunic@sumfak.hr ${ }^{3}$ Dr. sc. Karlo Beljan, e-mail: kbeljan@sumfak.hr

${ }^{4}$ Prof. dr. sc. Jura Čavlović, Zavod za izmjeru i uređivanje šuma, Šumarski fakultet Sveučilišta u Zagrebu, Svetošimunska 25, 10000 Zagreb, Hrvatska
} 


\section{INTRODUCTION} UVOD

Šume, uz ostala dobra za koje je zakonom određeno da su od interesa za Republiku Hrvatsku, imaju njezinu osobitu zaštitu (USTAV RH 2014, članak 52.) neovisno o vlasništvu nad njima. Zakonom se određuje način na koji ovlaštenici prava na šume i vlasnici šuma, kao dobra od interesa za Republiku Hrvatsku, mogu šumu upotrebljavati i iskorištavati, kao i naknada za ograničenja kojima su podvrgnuti (USTAV_RH 2014, članak 52.). Šume i šumska zemljišta zaštićuju se, upotrebljavaju, koriste i njima se gospodari na način određen Zakonom o šumama i posebnim propisima (ZOŠ, 2018, članak 2, stavak 2). Šumama i šumskim zemljištima koja nisu u vlasništvu Republike Hrvatske gospodare privatni šumoposjednici (ZOŠ, 2018, članak 16).

Privatne šume u Republici Hrvatskoj 2009. godine prema podacima prve Nacionalne inventure šuma prekrivaju 593.027 hektara ili gotovo $23 \%$ ukupne šumske površine (Čavlović 2010), a 2016. prema nacrtu šumskogospodarske osnove područja Republike Hrvatske 661.721 ha ili $24 \%$ (ŠGOP 2016). To svakako predstavlja značajan prirodni resurs, ali ipak je u velikoj mjeri bio zapostavljen sve do osnivanja Šumarske savjetodavne službe 2006. godine (UOŠsS 2006). Privatno šumarstvo osim što je zapostavljeno u gospodarskom smislu, bilo je i na marginama stručno-znanstvenih istraživanja.

Prva sociološka istraživanja šumoposjednika te obilježja sitnog privatnog šumoposjeda odnose se na područje sjeverozapadne Hrvatske (Čavlović 2004), međutim, često se rezultati navedenog istraživanja neopravdano preslikavaju i na nacionalnu razinu. Pregled stanja privatnog šumoposjeda, ali i širi presjek okolnosti gospodarenja privatnim šumama prikazuje Paladinić i dr. (2008). Analizom zakonodavnog okvira, stanja resursa privatnih šuma i organizacije gospodarenja autori zaključuju kako je privatni šumoposjed najdinamičnije područje šumarstva.

Istraživanje obilježja šumoposjednika i šumoposjeda u Hrvatskoj uključeno je i u nekoliko međunarodnih studija. Istražuje se spremnost na suradnju u izgradnji šumskih prometnica (Avdibegović i dr. 2010) ili na udruživanje u interesne grupe (Glück i dr. 2011), informiranost šumoposjednika (Avdibegović i dr. 2010), značenje šumoposjeda odnosno ciljeva gospodarenja te spremnost na proizvodnju drva za biomasu (Posavec i dr. 2015, Curman i dr. 2016). Spremnost na udruživanja u interesne udruge u Hrvatskoj započinje početkom 21. stoljeća (Paladinć i dr. 2008), slično kao i diljem jugoistočne Europe (Glück i dr. 2011). Utvrđeno je da postoji zainteresiranost za izgradnju prometnica i njihovo održavanje (Avdibegović i dr. 2010), slično kao i želja za proizvodnjom šumske biomase (Halder i dr. 2014., Posavec i dr. 2016.). S druge strane, ciljevi posjedovanja i gospodarenja šumoposjedom su se pokazali nejasni i ispre- pleteni (Posavec i Beljan 2012). Posjedovne i površinske značajke šuma šumoposjednika temeljene na analizama katastarskih podataka prema regijama istražuju Berta i dr. 2017. Zaključuju kako je privatni šumoposjed sitan i rascjepkan, pri čemu su utvrđene određene razlike između regija. Jedna od novijih analiza koja je obuhvatila privatne šume i njihovo vlasništvo u Republici Hrvatskoj završena je 2015. godine (Ostoić i dr. 2015). Spomenuta analiza rezultat je COST akcije kojoj je zadaća bila objedinjavanje postojećih podataka, informacija i spoznaja o privatnim šumama Europe, samim time i Hrvatske.

Javni značaj planiranja i gospodarenja privatnim šumama u okviru postojećeg modela šumarstva Republike Hrvatske ostvaruje se osnivanjem Šumarske savjetodavne službe 2006. godine (UOŠSS 2006), koja je zatim 2010. god. ukinuta (ZOŠ 2010) te se ponovo aktivira u okviru Poljoprivredno-šumarske savjetodavne službe od 2013. godine (ZOŠ 2013). Usporedno se uvodi raznodobno gospodarenje kao najprikladniji način gospodarenja sitnim privatnim šumoposjedom (POUŠ 2006). Šumarska savjetodavna služba i Ministarstvo poljoprivrede naručuju projekte koji za cilj imaju razviti modele izmjere i uređivanja privatnih šuma, ali i provedbe gospodarenja privatnim šumama. $U$ okviru toga je i izrada informativnog priručnika za šumoposjednike (Dubravac i dr. 2008). Međutim, dobiveni rezultati i razvijeni modeli primjenjuju se samo djelomično.

Prema svemu navedenom, određeni vidljivi i mjerljivi pomaci postoje, ali s druge strane brojni izazovi uspostave optimalnog gospodarenja privatnim šumama, kao i šumama općenito i dalje ostaju otvoreni. Cilj ovog rada je prikazati i analizirati različite utjecajne čimbenike na sadašnje stanje i gospodarenje privatnim šumama u Hrvatskoj. Na temelju analize i razmatranja postojećeg stanja predložiti korake unapređenja te smislenija rješenja organizacije planiranja gospodarenja i provedbe gospodarenja sitnim privatnim šumoposjedima. Pri tome će se polaziti od tri osnovne pretpostavke: a) prosječna obilježja šumoposjednika i šumoposjeda nisu presudna za unaprjeđenje gospodarenja privatnim šumama; b) aktiviranje gospodarenja svih privatnih posjednika šuma je neodrživo, preskupo i nepotrebno; c) usporedni sustav gospodarenja šumama prema vlasništvu otežava učinkovito i održivo gospodarenje privatnim šumama.

\section{MATERIJAL I METODE MATERIAL AND METHODS}

Spoznaje koje obilježavaju gospodarenje privatnim šumama su brojne, ali mogu se svrstati unutar dvije skupine. Prva skupina uključuje demografsko sociološka obilježja šumoposjednika, dok druga skupina predstavlja šumskogospodarska i strukturna obilježja privatnih šuma odnosno privatnih šumoposjeda. Temeljna obilježja privatnih 
a)

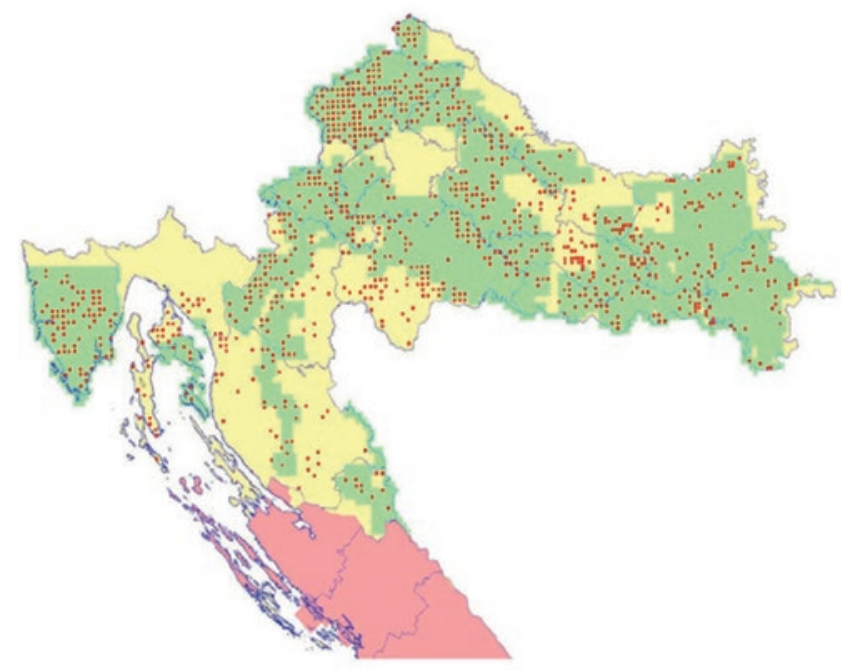

b)

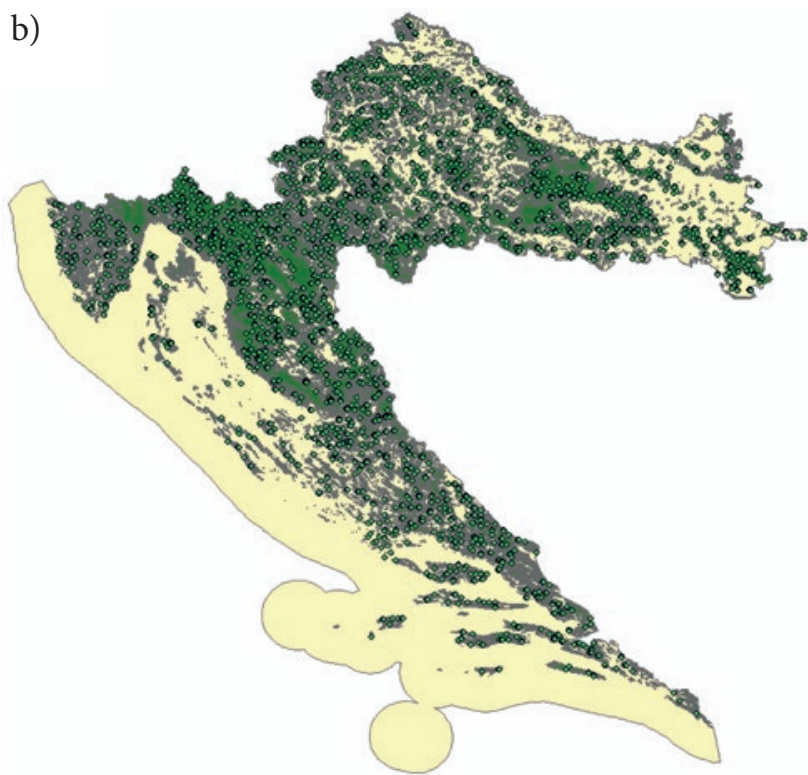

Slika 1. Prikaz uzorka terenskih ploha: a) u privatnim šumama za izradu šumskogospodarske osnove područja 2006. god (ŠGOP 2006); b) u svim šumama nacionalne inventure šuma 2006-2009. god (Čavlović 2010).

Figure 1. View of field sample plots: a) in private forests for elaboration of general forest management plan in 2006 (ŠGOP 2006); b) in all forests within the first NFI during 2006-2009 (Čavlović 2010).

šumoposjednika, s obzirom na opće postojeću nesređenost vlasničkih odnosa u zemljišnim knjigama, mogu se procijeniti neposrednim ili telefonskim anketiranjem odgovarajućeg uzorka ispitanika. Slijedom toga za analize obilježja šumoposjednika korišteni su podaci dobiveni vlastitim anketiranjem i podaci iz prijašnjih anketiranja. Korišteni su vrijedni podaci terenskog anketiranja $(\mathrm{N}=220) \mathrm{u}$ okviru istraživanja privatnih šuma Zagrebačke županije (Čavlović $2004)$ te terenskog istraživanja $(\mathrm{N}=350)$ šumoposjednika Sjeverozapadne Hrvatske (Posavec i dr. 2011). Detaljna sociološko demografska obilježja šumoposjednika provedenih istraživanja u već objavljenim radovima (Čavlović 2004, Posavec i dr. 2015, Curman i dr. 2016.) korištena su za usporedbu s aktualnim stanjem. Aktualne spoznaje na nacionalnoj razini zasnovane su na provedbi vlastitih istraživanja obilježja šumoposjednika telefonskim anketiranjem na uzorku od 1007 ispitanih koji su se izjasnili kao šumoposjednici. Telefonsko anketiranje je provedeno slučajnim odabirom unutar baze svih kućanstava u Hrvatskoj, te sužavanjem uzorka na šumoposjednička kućanstva na temelju izjašnjavanja anketiranih, sve dok se ne postigne ciljani uzorak od najmanje 1.000 ispitanih šumovlasnika. Na taj način, između ostalog su po prvi puta na nacionalnoj razini prikupljene informacije o sociološkim obilježjima šumoposjednika.

Strukturna obilježja šuma privatnih šumoposjednika na nacionalnoj razini kvalitetno su procijenjena već pri izradi Šumskogospodarske osnove područja za razdoblje 2006.2016. god. (ŠGOP 2006). S obzirom na to da privatne šume u najvećoj mjeri nisu bile uređene, provedena je neovisna izmjera na uzorku ploha projektiranom samo za tu namjenu. Nedostatak provedene inventure je izostanak informacija o intenzitetu i dinamici gospodarenja (sječa njege i obnove) u privatnim šuma. U međuvremenu, značajan iskorak predstavlja provedba prve nacionalne inventure kojom su šume neovisno o vlasništvu u pogledu uzorkovanja, izmjere i prikaza podataka tretirane jednako (Čavlović 2010).

Podaci operativnog uređivanja privatnih šuma koje je intenzivno započeto osnivanjem Šumarske savjetodavne službe, pri čemu je zaključno sa 2017. godinom pokriveno više od $2 / 3$ privatnih šuma, predstavljali su dobru podlogu za pridobivanje detaljnih informacija o prostornim i strukturnim obilježjima privatnih šuma. Prema tome, provedene nacionalne i uređajne inventure prostornog i strukturnog stanja privatnih šuma u ovom su radu poslužili kao osnovni izvor informacija. Podaci tih izmjera su korišteni za analizu stanja i potencijala privatnih šuma te promjena strukture drvne zalihe i sječa na razini pojedinih prostornih jedinica (podružnica Šumarske savjetodavne službe).

Razvoj i uspostava odgovarajućeg sustava (modela) šumarstva temeljen na zakonodavnim, organizacijskim i institucionalnim značajkama, kao ključna pretpostavka i okruženje za unapređenje gospodarenja privatnim šumama, predstavlja bitan predmet analize. Zakonski i pod-zakonski akti te strateški dokumenti, kako prošli tako i aktualni postojeći i nužni, predstavljaju materijal za analizu u ovom radu. Isto tako, institucije kao instrument upravljanja ili općenito reguliranja pojedinih djelatnosti ustrojene i organizirane na određeni način (javne, privatne, nevladine 
udruge) predmet su ovog istraživanja. U tome kontekstu, radi cjelovitog sagledavanja problematike gospodarenja privatnim šumama uključene su analize trenutnog stanja imovinskih odnosa koji su u Hrvatskoj razdvojeni između dvije institucije tj. državne geodetske uprave i općinsko građanskih sudova, odnosno između izvršne i sudbene vlasti.

\section{REZULTATI I RASPRAVA RESULTS AND DISCUSSION}

\section{Stanje, potencijal i intenzitet uporabe privatnih šuma - State, potential and use of private forests}

S nešto manje od četvrtine (24\%) Hrvatska pripada skupini europskih država s malim udjelom privatnih šuma. Mahom se to odnosi na istočnoeuropske zemlje s komunističkim povijesnim nasljeđem, kojeg obilježava potiskivanje privatnog vlasništva neposredno kroz nacionalizaciju, ali i posredno kroz previsoko oporezivanje te poticanje odricanja od imovine (Slika 2 a). Nadalje, u Hrvatskoj je prostorna raspodjela privatnih šuma vrlo nejednolika, gdje je na $50 \%$ površine udio manji od $10 \%$, odnosno gotovo je zanemariv (Slika 2 b).

Posljedica malog površinskog udjela i još manje ekonomske vrijednosti i gospodarskog značenja je izostanak uređivanja šuma, uključujući i raspolaganje informacijama o stanju strukture privatnih šuma te dosljednog gospodarenja. Ključni čimbenik predstavlja izrazitu usitnjenost i mali udio šumoposjeda većih od nekoliko desetaka a posebno od 100 ha, koji je usporediv s Latvijom (Slika 2 a). Privatni šumoposjedi su, sve do nedavno, uglavnom sitni, površinski rascjepkani i često degradirani, prostirući se uz rubove većih kompleksa državnih šuma, a njihovi korisnici koriste šumu uglavnom za svoje potrebe ili za sitnu lokalnu raz-

a)

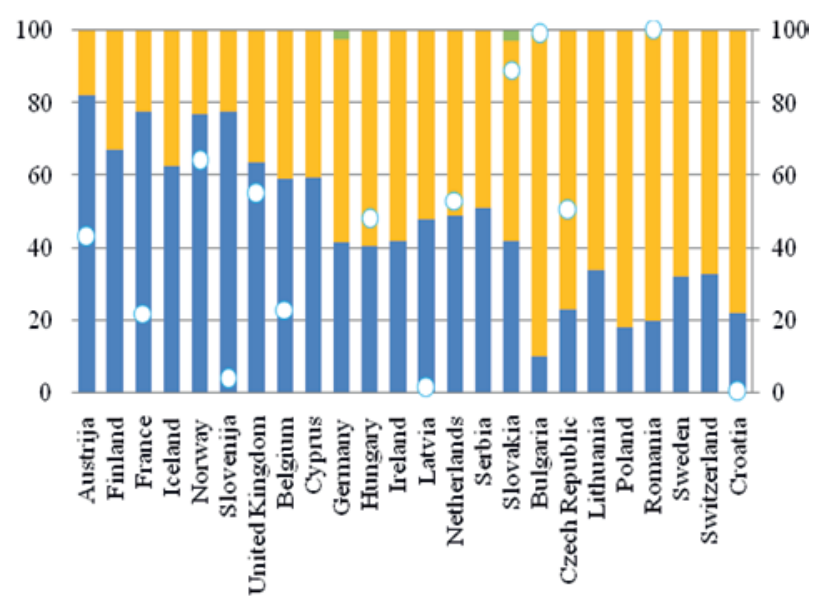

=Private $=$ Public $\equiv$ Other $\bigcirc$ Share of size classes greather than 100 ha mjenu ili prodaju (Kovačić 1997, Paladinić i dr. 2008). Sječe se provode bez stručne podloge i vođenja, već prema potrebi korisnika, ili gospodarenje, odnosno sječa u potpunosti izostaje.

U odnosu na prvi sveobuhvatni prikaz privatnih šuma u Šumskogospodarskoj osnovi područja iz 1996. (ŠGOP 1996), sljedeće procjene (ŠGOP 2006, ŠGOP 2016) ukazuju na značajno povećanje površine privatnih šuma (Slika 3 a). To je posljedica činjenice što su se prve procjene zasnivale na stanju prema katastru koje nije odgovaralo stvarnom stanju te povratu nacionaliziranih šuma. Prema tomu, navedeno povećanje se odnosi na velik dio površina na bivšem poljoprivrednom zemljištu koje je u naravi šuma ili je u zarastanju. Osim toga, određeni dio privatnih šuma predstavlja zaštitne i/ili krške šume (preko 110.000 ha u Dalmaciji). Iz Slike 3a uočljivo je kako ukupno povećanje tijekom 20-godišnjeg razdoblja iznosi oko 160.000 ha, pa tako prema posljednjim podacima šume privatnih šumoposjednika obuhvaćaju 620.000 ha, što čini oko 24 \% šuma Hrvatske.

Drvna zaliha po ha u odnosu na stanje prije 10 godina se neznatno smanjila, dok se u odnosu na stanje prije 20-ak godina značajno povećala u svim područjima (Slika 3 a). Prema podacima ŠGOP cjelokupno gledano ukupna drvna zaliha se tijekom zadnjih 20 godina povećala za oko 5,5 mil. $\mathrm{m}^{3}$ na postojećih $83,7 \mathrm{mil} . \mathrm{m}^{3}$. To se dobro podudara s procjenom drvne zalihe privatnih šuma od $80,8 \mathrm{mil} . \mathrm{m}^{3}$ kao stanje prije 10 godina prema CRONFI (Čavlović 2010). Povrat dijela kvalitetnih državnih šuma, rast drvne zalihe zaraštanjem poljoprivrednog zemljišta i akumuliranje prirasta dovelo je do povećanja drvne zalihe i vrijednosti privatnih šuma, što se može očekivati i u budućem razdoblju. Drvna zaliha od 250 do $350 \mathrm{~m}^{3} /$ ha na kontinentalnom području (Slika 3a) uz primjenu raznodobnog načina gospodarenja

b)

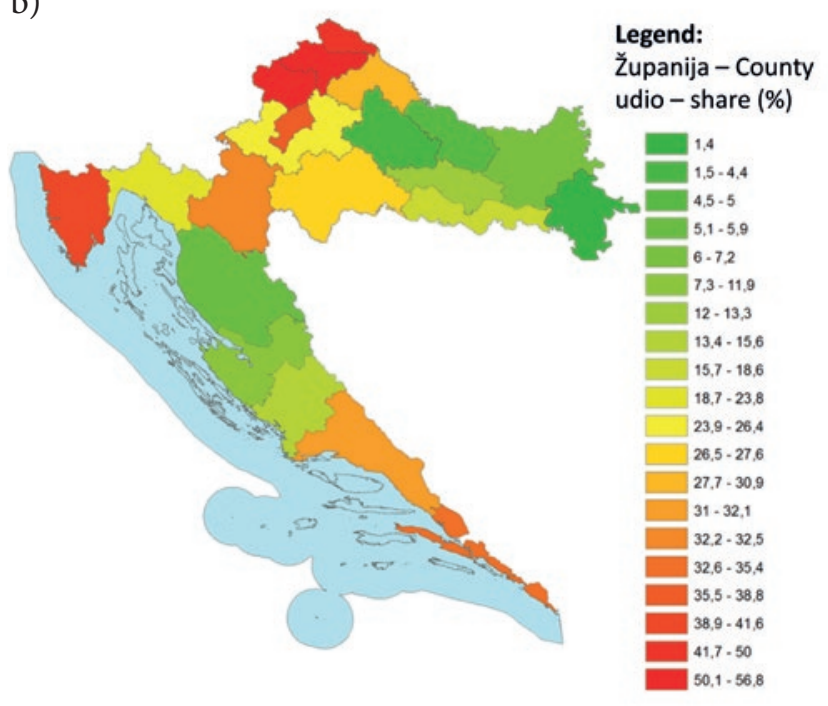

Slika 2. Prikaz: a) udjela šuma prema vlasništvu u europskim državama; b) udjela privatnih šuma u Hrvatskoj po županijama Figure 2. Overview of: a) share of forests according to ownership in European countries; b) share of private forests in Croatia by counties 

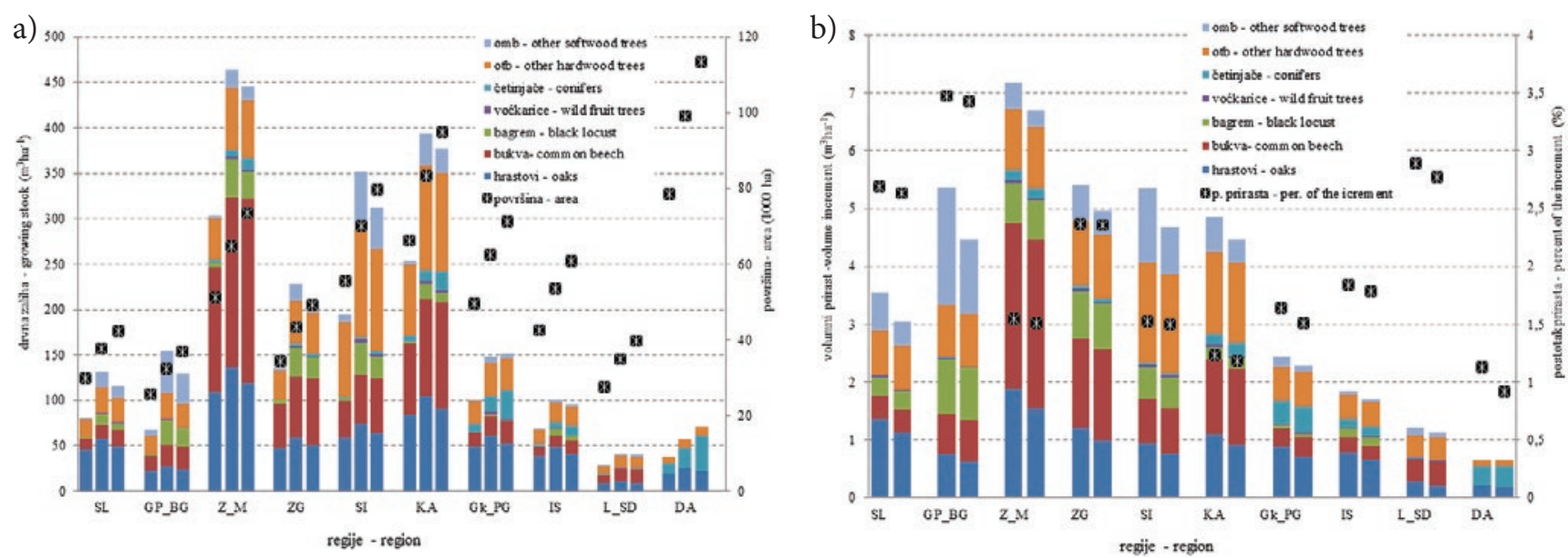

Slika 3. Prikaz promjena stanja privatnih šuma prema skupinama vrsta drveća i Podružnicama ŠSS: a) drvna zaliha i površina (ŠGP $1996 ., 2006$. i 2016.); b) godišnji volumni prirast (ŠGP 2006. i 2016.)

Figure 3. Changes of private forest resources according to tree species and Units of advisory services: a) growing stock and area (GFMP 1996., 2006. i 2016.); b) annual volume increment (GFMP 2006. i 2016.)

te udio pionirskih razvojnih stadija ukazuje na izniman potencijal privatnih šuma i njihovog budućeg gospodarenja.

Uz drvnu zalihu tečajni volumni prirast značajan je pokazatelj potencijala privatnih šuma. Postojeći podaci ukazuju da i uz relativno mali intenzitet gospodarenja (sječe) postoji dinamičan razvoj strukture šuma u privatnom vlasništvu (Slika 3), što uz veliko bogatstvo vrsta drveća i degradacijskih stadija predstavlja velik izazov planiranju i gospodarenju. U tome kontekstu detaljni i objektivni podaci o strukturi sječa i njihovim učincima na promjene strukture dobit će se provedbom druge nacionalne inventure šuma.

Uslijed intenziviranja uređivanja i posljedičnog gospodarenja privatnim šuma od 2006. godine dolazi do povećanja sječa, posebno unutar strukturno zrelih šuma, koje su prema podacima nacionalne inventure iznad očekivanja.
Prosječan godišnji intenzitet sječe od 1,27\% koji iznosi oko $50 \%$ prirasta ako se uzme da je prosječan postotak godišnjeg prirasta oko $2,5 \%$ i drvna zaliha od $150,7 \mathrm{~m}^{3} / \mathrm{ha} \mathrm{su}$ mali i ukazuju na izostanak gospodarenja u velikom dijelu šuma. $S$ jedne strane, sječa od oko 5-6 $\mathrm{m}^{3} /$ ha (Slika 4 b) u odnosu na prirast od $4-5 \mathrm{~m}^{3} /$ ha (Slika 3 b) u sjevernim i središnjim područjima Hrvatske ukazuje na postojanje i intenzivnog gospodarenja. Nasuprot tomu, mali intenzitet sječe unatoč značajnoj drvnoj zalihi uočljiv je na Kordunu i Baniji kao vjerojatna posljedica depopulacije područja (Slika $4 \mathrm{ab}$ ). To se vjerojatno u međuvremenu promijenilo s obzirom da se podaci sječa odnose na razdoblje 2004-2009 godine. Općenito, može se očekivati daljnje intenziviranje gospodarenja i sječa kao posljedica pridolaženja strukturno zrelih stadija privatnih šuma, povrata državnih šuma, po-
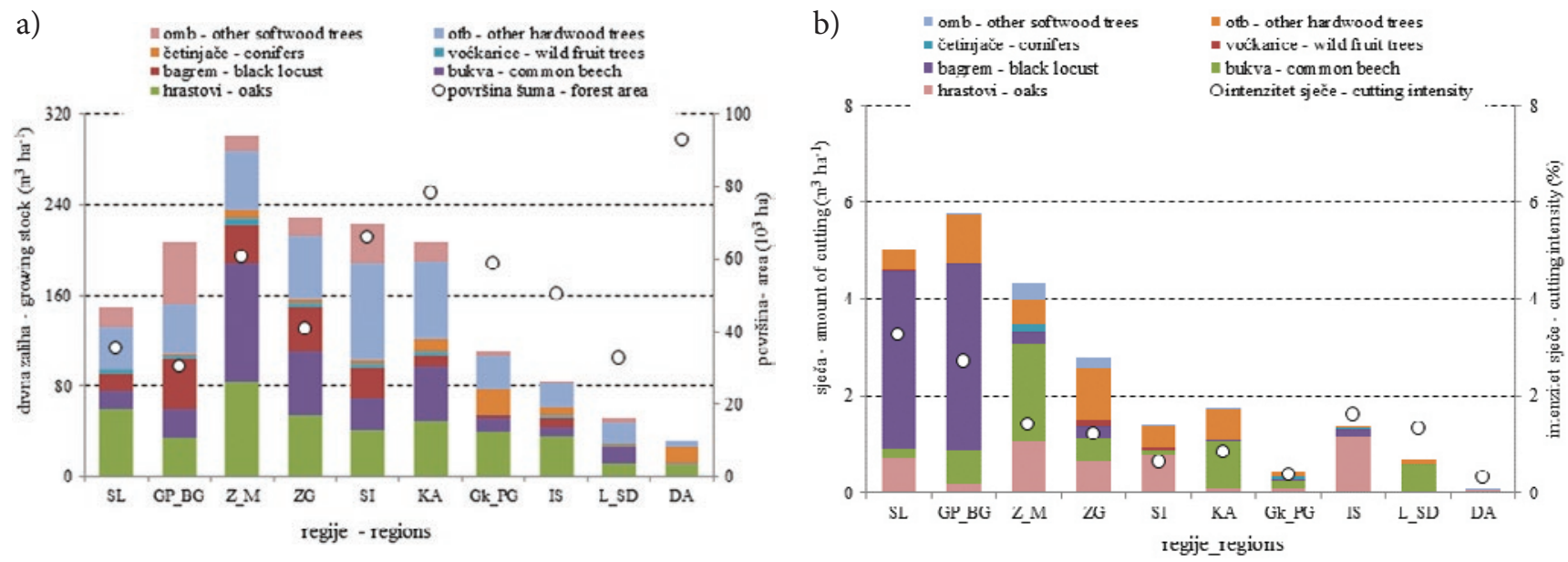

Slika 4. Prikaz stanja i korištenja privatnih šuma po Podružnicama ŠSS prema nacionalnoj inventuri šuma (Čavlović 2010): a) drvna zaliha i površina; b) sječa i intenzitet sječe

Figure 4. Overview of state and use of private forests by Units of forest advisory according to NFI data (Cavlovic 2010): a) growing stock and area; b) volume cut and intensity of cut 

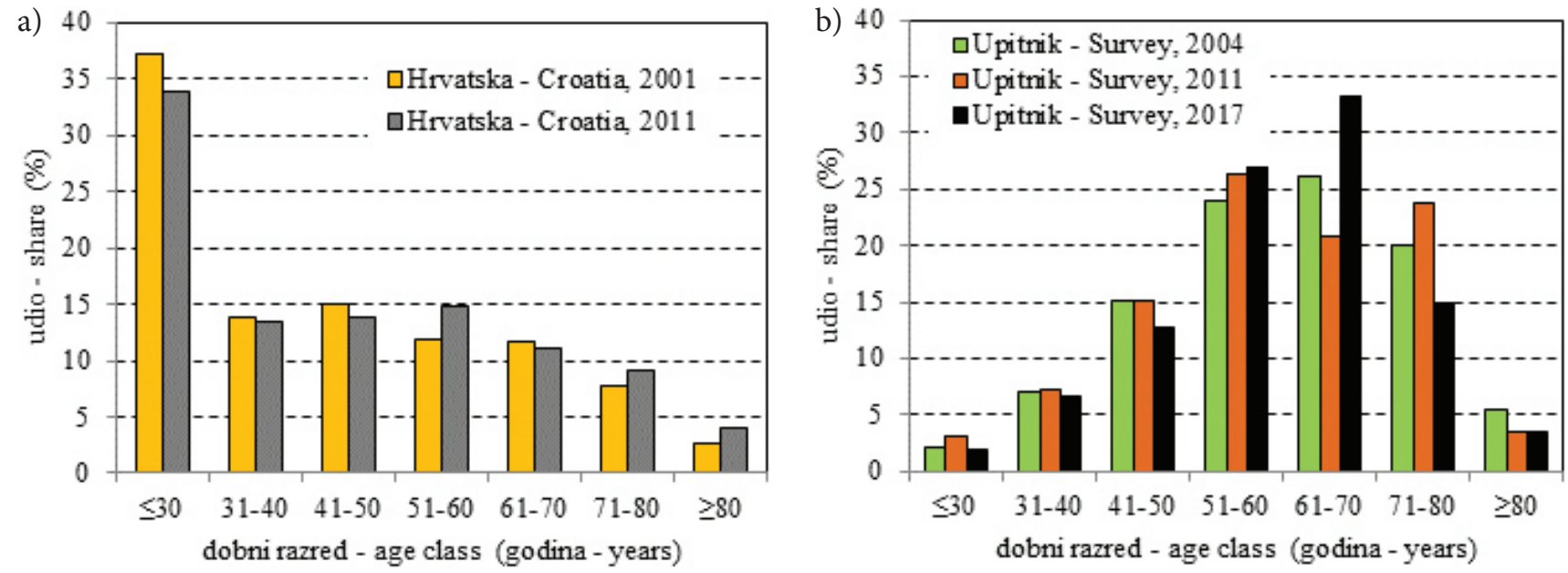

Slika 5. Prikaz dobne strukture: a) opće populacije (popis stanovništva 2001. i 2011.); b) šumoposjednika (anketiranje prema Čavlović 2004., Posavec i dr. 2011., Teslak i dr. 2017.)

Figure 5. Age-class distribution of: a) total residents of Croatia (survey 2001 and 2011); b) private forest owners (survey according to Čavlović 2004, Posavec et al. 2011, Teslak et al. 2017)

rasta cijene drva, pada poljoprivredne proizvodnje, ali i poticanja gospodarenja šumama od strane države.

Stanje strukture, sječa i prirasta ukazuje na činjenicu kako je generacija šumoposjednika na odlasku znala gospodariti i sačuvati svoju šumu unatoč izostanku stručne podrške uglavnom na temelju naslijeđenog znanja i iskustva. S druge strane, šuma je ekosustav koji se uspješno razvija i bez intervencija posebice u uravnoteženom okolišu. Aktualne mlađe, a poglavito buduće generacije neće se moći osloniti na naslijeđena znanja jer vrlo rano napuštaju ruralni prostor, stoga je nužno njihovo zadržavanje i naknadne edukacije (Lopez i dr. 2015), ustupanje gospodarenja profesionalcima ili odricanje od vlasništva. Stručna potpora iznimno je važna u kontekstu klimatskih promjena i posljedično sve izraženijih vremenskih ekstrema. Upravo zato iznimno je važna institucionalna i zakonodavna potpora države.

\section{Prosječna obilježja šumoposjednika i šumoposjeda nisu odlučujuća za unapređenje gospodarenja privatnim šumama - An average characteristics of private forest owners are no precedent for improvement of forest management}

Oblikovanje strategija gospodarenja privatnim šumama oslanja se na poznavanje obilježja i zahtjeva šumoposjednika koje su predmet brojnih znanstvenih istraživanja (Ní Dhubháin i dr. 2007, Eggers i dr. 2004, Boon i Melby 2007). $\mathrm{Na}$ nacionalnoj razini utvrđeno je da prosječan šumoposjednik je muškarac, starosne dobi iznad 60 godina sa završenom ili nezavršenom osnovnom ili srednjom školom (Tablica 1), što se podudara s prije provedenim istraživanjima (Čavlović 2004, Posavec i dr. 2014). Dobna struktura privatnih šumoposjednika značajno odstupa od opće po- pulacije sa dvostruko većim udjelom dobnih skupina iznad 50 godina (Slika 5). Stanje i rast razine obrazovanja šumoposjednika bolje se podudara s općom populacijom, uz određena odstupanja s obzirom na povećani udio šumoposjednika bez formalnog obrazovanja i izrazito mali udio visokoobrazovanih (Slika 6).

Prikazani rezultati sociodemografskih obilježja nisu ohrabrujući, slično kao i u nekim drugim zemljama (npr. Haugen i dr. 2016), a takvi trendovi se mogu očekivati i dalje. U tome smjeru iznimno je važna raščlamba šumoposjednika u skupine s obzirom na spremnost za aktivnim gospodarenjem i zahtjeve prema šumoposjedu. Stoga su nužna istraživanja tipologije šumoposjednika i njihovih preferencija (Ingemarson i dr. 2006, Ficko i dr. 2017) radi oblikovanja modela gospodarenja prilagođenih različitim zahtjevima uz zadržavanje visoke razine stručno utemeljenog gospodarenja na dijelu privatnih šuma. Pri tome, zbog razmjerno niske razine sređenosti imovinsko-pravnih odnosa, potpuno i objektivno spoznavanje obilježja privatnih šumoposjeda je vrlo složen i otežavajući proces.

Podaci koji se uobičajeno koriste pri općenitom prikazu privatnih šuma i šumarstva su: 600.000 šumoposjednika od kojih 99 \% ima šumoposjed manji od 1 ha; izostanak gospodarenja i degradiranje šuma. Potpunim aktiviranjem gospodarenja šumskog resursa na 620.000 ha s godišnjim prirastom od 2,2 mil. $\mathrm{m}^{3}$ ostvarila bi se velika gospodarska korist za zajednicu. Navedene informacije bez detaljnije raščlambe stanja, potencijala i bitnih činjenica mogu imati površno i u nekim slučajevima manipulativno značenje. Postavlja se osnovno pitanje: smatraju li se posjednicima i svi oni koji posjeduju čestice koje su u prirodi šuma? Informacije o obilježjima šumoposjednika i šumoposjeda mogu se pridobiti pomoću dva pristupa: postojeće baze podataka i 

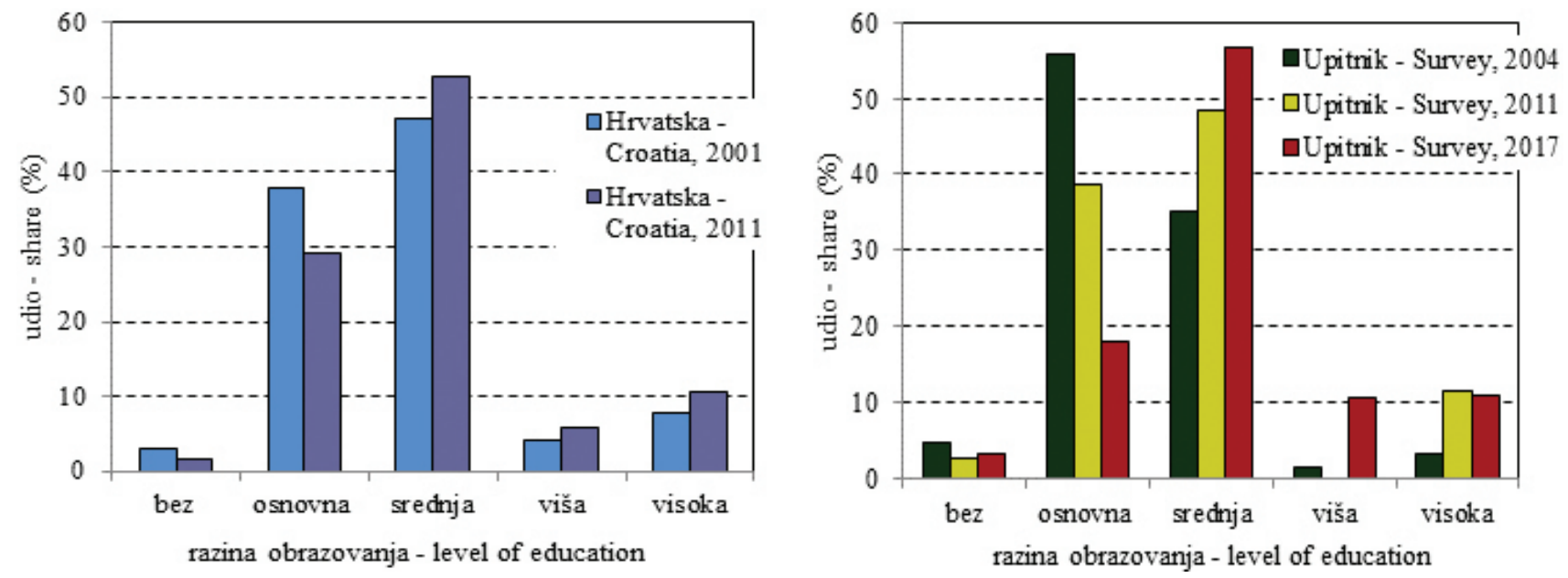

Slika 6. Obrazovna struktura: a) opće populacije (popis stanovništva 2001. i 2011.); b) šumoposjednika (anketiranje prema Čavlović 2004., Posavec i dr. 2011., Teslaki dr. 2017.)

Figure 6. Education levels distribution of: a) total residents of Croatia (survey 2001 and 2011); b) private forest owners (survey according to Čavlović 2004, Posavec et al. 2011, Teslak et al. 2017)

neposrednim anketiranjem, čime ne mora biti zajamčena pouzdanost tih informacija.

Od već postojećih baza podataka najčešće se koristi posjedovno stanje iz katastra koje sadrži posljednje ažurirano stanje posjednika po katastarskim česticama. Upisani posjednici stvarno ne postoje najčešće zato što nisu živi ili njihov status nije poznat. Poseban problem predstavlja brojno suposjedništvo, pri kojemu se svakom šumoposjedniku pridružuje njegov idealni dio s obzirom na udio i broj suposjednika, a u biti je možda samo jedan od njih korisnik čestice. Pored toga, brojni posjednici posjeduju više katastarskih čestica upisanih na više posjedovnih listova, tako da posjedovni list ne može biti jedinica šumoposjeda kako je to prikazano u nekim istraživanjima (npr. Berta i dr. 2017). Šumoposjed trebaju sačinjavati sve čestice ili dijelovi čestica na kojima je u naravi šuma, a kojima gospodari pripadajući posjednik, ali nikako samo čestice upisane na pojedinom posjedovnom listu. Osim toga, često u istom kućanstvu svi njegovi članovi mogu biti posjednici više cijelih ili dijelova katastarskih čestica, no u stvarnosti je to jedan šumoposjed kojim to kućanstvo zajednički gospodari. Prema navedenom, jasno je da se podaci posjedovnog sta-

Tablica 1. Prosječna sociodemografska obilježja šumoposjednika

Table 1. Average socio-demographic characteristics of researched private forest owners

\begin{tabular}{|c|c|c|c|}
\hline Anketa - Survey & Čavlović 2004 & Posavec i dr. 2011 & Teslak i dr. 2017 \\
\hline Metoda - Methods & Neposredno - face to face & Neposredno - face to face & Telefonsko - by telephone \\
\hline uzorak - sample & 202 & 347 & 1007 \\
\hline Područje - Survey area & $\begin{array}{l}\text { Zagrebačka županija Grad Zagreb } \\
\text { - Zagreb County and City of Zagreb }\end{array}$ & $\begin{array}{c}\text { Sjeverozapadna Hrvatska - North- } \\
\text { west Croatia }\end{array}$ & $\begin{array}{c}\text { Republika Hrvatska - Republic of } \\
\text { Croatia }\end{array}$ \\
\hline \multicolumn{4}{|c|}{ Prevladavajuće obilježje - Dominant feature } \\
\hline Spol-Sex & Muški - Male; $68.3 \%$ & Muški - Male; 67,3\% & Ženski - Female; 50,4 \% \\
\hline $\begin{array}{l}\text { prosječna dob (godina) - average } \\
\text { age (year) }\end{array}$ & 60,5 & 59,0 & 60,1 \\
\hline $\begin{array}{l}\text { razina obrazovanja - level of } \\
\text { education }\end{array}$ & Srednjoškolsko - Highschool; 55,8\% & Srednjoškolsko - Highschool; 48,5\% & Srednjoškolsko - Highschool; 56,6\% \\
\hline Zanimanje - Profession & $39,6 \%$ umirovljenici - pensioners & $48,8 \%$ umirovljenici - pensioners & $56,1 \%$ umirovljenici - pensioners \\
\hline $\begin{array}{l}\text { Prihod kućanstva - household } \\
\text { income }\end{array}$ & - & - & 2.001-3.500 KN; $24,5 \%$ \\
\hline $\begin{array}{l}\text { Prosječna površina šumoposjeda - } \\
\text { average area of forest ownership } \\
\text { (ha) }\end{array}$ & 0,83 & 1,94 & 2,1 \\
\hline $\begin{array}{l}\text { Broj parcela posjeda - property } \\
\text { fragmentation level }\end{array}$ & - & Pet i više - Five and more; $76,3 \%$ & Tri i više - Three and more; $51,7 \%$ \\
\hline
\end{tabular}


nja iz katastra moraju vrlo oprezno koristiti i interpretirati. Stvarno stanje je takvo da se trenutno ne može utvrditi točan broj šumoposjednika, njihovi osnovni podaci, površina šumoposjeda, usitnjenost i slično. Drugim riječima, točnost podataka koji su na raspolaganju je upitna. S obzirom na prethodno navedeno, pitanje je koliko se podaci koji se dobiju neposrednim anketiranjem šumoposjednika mogu smatrati vjerodostojnima, te koliko su podložni subjektivnosti i pogreškama (Egan i Jones 1995, Ficko i Bončina 2014). Prema tomu, dobivena informacija o šumoposjedu, na primjer površina, osobna je šumoposjednikova procjena stvarnog stanja.

Procijenjena obilježja prosječnog šumoposjeda u sebi mogu sadržavati veliku različitost i pogreške pristupa interpretacije i uporabe podataka, međutim to niti ne može biti podloga za oblikovanje smjernica unapređenja gospodarenja privatnim šumama. Isto tako, svatko tko posjeduje česticu zemljišta na kojoj raste šumska vegetacija nije šumoposjednik, kao što ni svatko tko posjeduje poljoprivredno zemljište nije poljoprivrednik te se prema njemu niti ne oblikuje šumarska, odnosno poljoprivredna politika. Identificiranje pojedinih tipičnih skupina šumoposjednika s obzirom na ciljeve, zahtjeve i razinu spremnosti za gospodarenjem, podloga je za oblikovanje strategija i postupaka unapređenja gospodarenja šumama, te selektivno i postupno poticanje i usmjeravanje zainteresiranih i aktivnih šumoposjednika. Te u konačnici njihovo udruživanje u cilju ostvarivanja zajedničkih interesa.

\section{Aktiviranje svih privatnih posjednika šuma za gospodarenje je neodrživo i nepotrebno - Activating of all private forest owners for forest management is unsustainable and unnecessary}

Kako u Hrvatskoj ne postoje cjelovite i sređene baze podataka o privatnim šumoposjednicima, otežano je uzorkovanje za potrebe anketnog istraživanja. U takvom slučaju moguć je pristup uzorkovanju metodom slučajnog odabira telefonskim anketiranjem cjelokupnog stanovništva (Teslak 2017), pri čemu se dobije udio privatnih šumoposjednika u odnosu na ukupnu populaciju kao i presjek obilježja postojećih šumoposjednika. Na taj način dobiveni rezultati imaju pretežito znanstvenu upotrebu, ali se mogu koristiti kao objektivna podloga za oblikovanje strategija i metoda gospodarenja privatnim šumama (Eggers i dr. 2014, Nielsen-Pincus i dr 2015).

Aktivni šumoposjednici koji nastoje gospodariti svojim šumoposjedom i urediti imovinsko-pravne odnose jednostavnije se identificiraju putem Upisnika šumoposjednika, Saveza udruga šumoposjednika, i evidencije Šumarske savjetodavne službe. Evidentiranje u Upisnik šumoposjednika potrebno je i dalje poticati kroz mogućnosti dobivanja poticajnih sredstava, ali i ostvarivanja mogućnosti stavljanja šumskih proizvoda na tržište. Trenutno je u bazi Upisnika upisano oko 2.800 šumoposjednika što je relativno malo, no taj broj je stvaran i raste, a povezan je sa već nabrojanim činjenicama. Oni predstavljaju jezgru za provođenje i unapređenje gospodarenja u privatnim šuma te motor daljnjeg razvoja.

Jasno da preostaje i nadalje značajna površina privatnih šuma koja ostaje izvan kontroliranog i stručno usmjeravanog gospodarenja. Međutim, s obzirom na obilježja privatnih šuma i šumoposjeda, teško je za očekivati kako će se u kratkom vremenu svim privatnim šumama aktivno gospodariti. Uključivanje čestice i njenog posjednika u Program gospodarenja ne mora značiti aktiviranje gospodarenja. Isto tako, aktiviranje gospodarenja nije niti nužno, jer šume mogu i bez gospodarenja (sječe), čime neće biti ugrožena njena stabilnost, dok će na gubitku biti zajednica i vlasnici šuma. $S$ druge strane, podaci ukazuju da se u većini privatnih šuma gospodari tj. sječe (Slika 4 b), istina često bez stručne podloge, no opet $s$ obzirom na obilježja tih šuma (udio, usitnjenost, sukcesija) nije to najveći problem hrvatskog šumarstva. Biljne bolesti i klimatske promjene puno su ozbiljnija ugroza svim šusmama neovisno o vlasništvu.

Država kroz odgovarajući institucionalni okvir treba i mora sprječavati i suzbijati bespravne sječe, krađu drva te stavljanje na tržište drva iz šuma koje nisu obuhvaćene Upisnikom. Time će se poticati okrupnjavanje i sređivanje imovinskopravnih odnosa te provođenje stručno utemeljenog gospodarenja šumama. Ovdje je bitno naglasiti da je šumoposjednik samo onaj tko je upisan u Upisnik, a ostali su samo posjednici ili vlasnici čestica na kojima raste šuma. U skladu s tim na jedne i druge bi se trebale odnositi različite skupine prava i obveza. Primjerice, vlasnici šuma koji nisu upisani u Upisnik mogu šumu koristiti samo za vlastite potrebe. Svi oni koji stavljaju šumske proizvode na tržište moraju zatražiti provedbu stručne doznake u skladu sa šumskogospodarskim planom. Naime, nedopustive su sadašnje odredbe koje omogućavaju sječe bez stručne doznake, istina to se odnosi samo na šume koje se u katastru vode kao ne šumske kulture, ali ipak uz mogućnost stavljanja drva na tržište. Očekivano je da stručnost pri planiranju gospodarenja, provedbi i kontroli gospodarenja, uvažavajući obilježja privatnog šumarstva pri tome mora biti na najvišoj razini. Time bi se steklo povjerenje javnosti, pa i šumoposjednika.

Osnovne pretpostavke aktiviranja gospodarenja privatnih šumoposjednika su rješavanje vlasničkih odnosa te okrupnjavanje posjeda. Dva su moguća modela rješavanja tih problema. Jedan je kroz šire zahvate komasacije nekog područja, gdje država ima vodeću ulogu te planira, provodi i nadzire proces. Država ima ulogu medijatora između pojedinaca, vlasnika zemljišta, ali i sudjeluje u procesu kao najznačajniji vlasnik zemljišta. Obično takvi projekti uključuju uređenje zemljišta u smislu odvodnje, pristupnih putova i sl. Predno- 


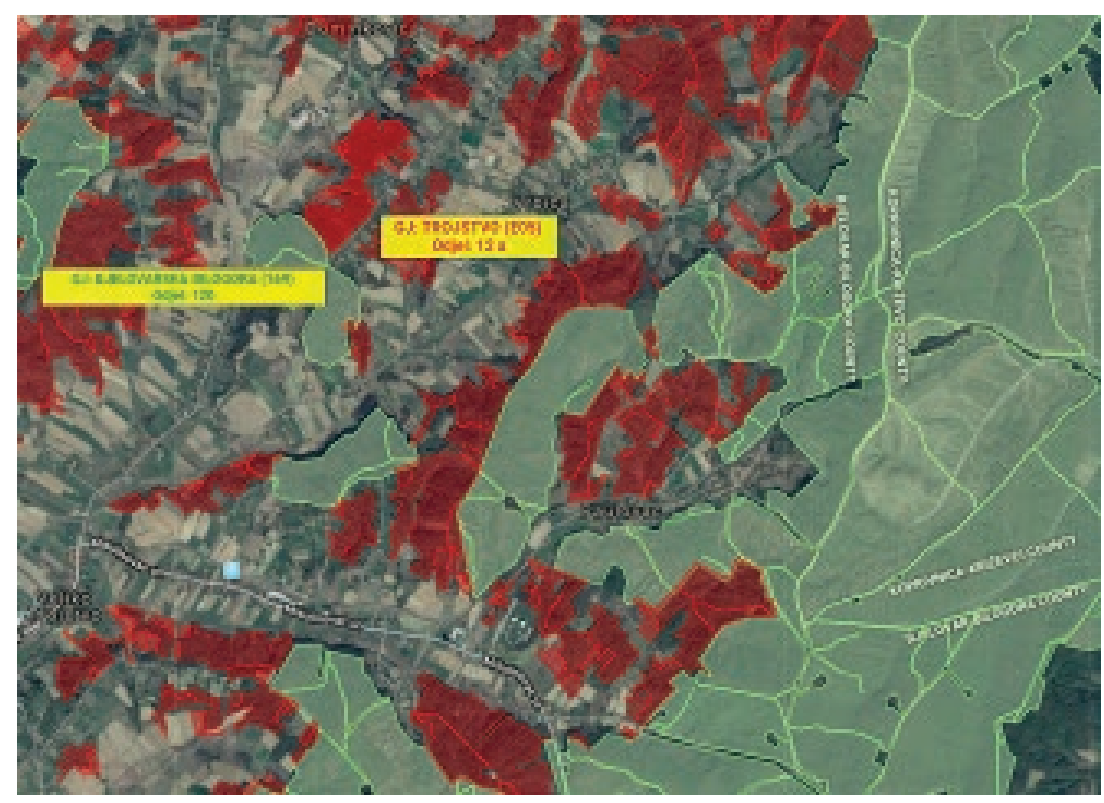

Slika 7. Prikaz gospodarske podjele dijela gospodarske jedinice privatnih (crveno) i gospodarske jedinice državnih šuma (zeleno) (http://javni-podaci-karta.hrsume.hr/)

Figure 7. View of forest division of part of management unit of private (red) and management unit of state forests (green) (http://javni-podaci-karta.hrsume.hr/)

sti takvog tipa procesa je brzina odvijanja i jednostavnost za sitne privatne šumovlasnike. Drugi model se temelji na poticanju pojedinaca da sami rješavaju vlasničke odnose i uređuju zemljište. Država potiče i regulatorno olakšava proces. Prednost mu je nizak trošak za državu, a izričit nedostatak je sporost odvijanja. Ova dva modela najčešće se odvijaju paralelno. S obzirom na stanje u vlasničkim odnosima te druge okolnosti u Hrvatskoj, potrebno je žurno početi provoditi oba modela te na taj način omogućiti prikladno gospodarenje na što više površina u kraćem vremenu.

\section{Usporedni sustav gospodarenja šumama prema vlasništvu - The parallel forest management system according to forest property}

Kao posljedica vlasničke strukture (relativno malog udjela sitnih privatnih šuma), hrvatska šumarska struka i znanost tradicionalno je bila uglavnom koncentrirana i usmjerena na gospodarenje šumama u državnom vlasništvu. Zbog činjenice da se radi o jednom vlasniku šume - državi koja istodobno promiče i jamči opće i dugoročne interese gospodarenja šumama te zbog kompaktnih i velikih kompleksa šuma, učinkovita provedba i primjena načela održivog gospodarenja u državnim šumama je jednostavnija. Tako, u državnim šumama prevladava regularni način gospodarenja uz obnavljanje jednodobnih sastojina oplodnom sječom, u bjelogoričnim šumama poglavito vrijednim šumama svjetloljubivih hrastova za koje raznodobni načini gospodarenja nisu prihvatljivi. Radi uspostave i podržavanja uravnoteženog gospodarenja taj način gospodarenja za- htijeva razmatranje većih površina šuma za koje se jedinstveno planira i provodi gospodarenje.

Gospodarenje na razini sitnog privatnog šumoposjeda obilježeno je ostvarenjem uskih i kratkoročnih interesa šumovlasnika uz nestručno i neodrživo gospodarenje povezano i s premalim šumoposjedom. Zbog toga, uspostava i podržavanje ravnoteže između ekoloških i šumskouzgojnih potreba šuma, te interesa i zahtjeva šumoposjednika i zajednice je temeljni izazov gospodarenja privatnim šumama. Uspostava uravnotežene šume, kao pretpostavka trajnosti gospodarenja, pri prebornom i raznodobnom gospodarenju zahtijeva manju površinu šume te su stoga prikladniji za sitne privatne šumoposjede (Čavlović 2013). Prema tomu, ciljana najmanja površina šume od 30-50 ha, odnosno skupine šumovlasnika s navedenom najmanjom površinom šumoposjedom, osigurala bi održivost gospodarenja i uspostavu uravnoteženog niza sastojina na razini šumoposjeda. Preborno gospodarenje s dugom tradicijom vezano je uz jelove šume na području Hrvatske i Dinarida općenito (Čavlović i dr. 2006, Bončina i dr. 2014), te uključuje i prva uređivanja privatnih šuma u Gorskom kotaru (Pleše 2008). Za ostale privatne šume sve do 2006. godine i uvođenja raznodobnog načina gospodarenja (POUŠ 2006) nije bilo prikladnog modela gospodarenja. Za očekivati je kako će primjena raznodobnog načina gospodarenja postupno pozitivno utjecati na unapređenje stanja i gospodarenja privatnim šumama u sitnom privatnom vlasništvu (Čavlović 2004).

Odgovarajuća prostorna razdioba šuma predstavlja temeljni okvir za učinkovito usklađivanje ciljeva, planiranja i gospo- 
darenja šumama između operativne i strateške razine. Početkom 90-tih kada su započeta prva uređivanja šuma (oblikovanje gospodarskih jedinica) još neuređenih područja (Dalmacija) te intenziviranje uređivanja privatnih šuma, usvojen je pristup kako sve šume neovisno o vlasništvu unutar jedne gospodarske jedinice trebaju biti obuhvaćene jedinstvenim planom gospodarenja (POUŠ 1994, Meštrović 1995). Činjenica je da se od toga pristupa vrlo brzo odustalo (POUŠ 1997), te je ustanovljen sustav zasebne gospodarske podjele na gospodarske jedinice privatnih šuma od kojih je velik broj (407) s izrađenim Programima gospodarenja. Bez razmatranja prednosti i nedostataka pojedinog pristupa kao zasebne teme, može se utvrditi da je učinkovitost primjene određenog pristupa povezana s uspostavljenim modelom šumarstva. Najveći dio uređen je u razdoblju nakon osnivanja Šumarske savjetodavne službe 2006. godine (UOŠSS 2006), a posebno intezivno privatne šume uređuju se unatrag nekoliko proteklih godina.

Nasuprot postojećem sustavu, fleksibilniji pristup koji bi omogućavao objedinjavanje šuma neovisno o vlasništvu na operativnoj razini u jedinstvenu plansko gospodarsku cjelinu (gospodarsku jedinicu), posebno u slučajevima gdje se međusobno prostorno isprepliću (Slika 7), intuitivno upućuje na učinkovitije planiranje i gospodarenje šumama. Takva gospodarska jedinica/plan gospodarenja bila bi složenija i heterogenija u pogledu različitosti ciljeva i zahtjeva gospodarenja, tipova šuma i načina gospodarenja, što ne mora biti ograničavajuće s obzirom na zahtjevnije uređivanje šuma i provedbu gospodarenja. U smislu fleksibilnosti, tretiranje i primjena pojedinih odredbi može biti različita prema šumama različite kategorije vlasništva (na primjer, premalo izvršenje propisa u privatnim šumama koje je na razini privatnih šuma ili čak na razini cijele gospodarske jedinice ispod dozvoljenog odstupanja ne treba biti razlog izvanredne revizije plana gospodarenja). Prostorno vremenska koncentracija postupaka uređivanja šuma, kao i postupaka neposrednog gospodarenja unutar takvih integralnih gospodarskih jedinica kojih bi u konačnici bio manji broj, cjelokupno i dugoročno gledano bi rezultiralo manjim troškovima i većom učinkovitošću. Pretpostavka za to je postojanje dobro ustrojene jedinstvene javne šumarske službe.

Osnivanje Savjetodavne službe za privatne šume bio je mali i nepotpuni korak prema ustrojavanju javne šumarske službe. Traženja i nedovršenost institucionalnog okvira u kojemu i na toj razini postoji određena razdvojenost između državnih i privatnih šuma se ogledaju u sljedećem: naknadno ukidanje Savjetodavne službe i njeno vraćanje u trgovačko društvo Hrvatske šume d.o.o.; konačno pripajanje Savjetodavne službe za privatne šume u poljoprivrednu savjetodavnu službu; značenje Hrvatskih šuma koje su kao javno poduzeće do 2002. godine imale javne ovlasti, a koje nakon toga formalno prestaju njihovim preoblikovanjem u trgovačko društvo; te sektor šumarstva u resornom Ministarstvu koje nije dovoljno kapacitirano za obnašanje javnih ovlasti.

Očekivana uspostava jedinstvene javne šumarske službe, uz funkcionalno razdvajanje upravljanja i planiranja od neposrednog gospodarenja šumama učinkovito bi objedinila strateško i operativno planiranje gospodarenja svim šumama. Takav institucionalni okvir bi od najviše polazišne razine, od strateške prema operativnim razinama, predstavljao temeljnu pretpostavku i priliku unapređenja stanja i gospodarenja privatnim šumama. Kroz jedinstveni sustav hijerarhijskog, prostornog i vremenskog usklađivanja politika, strategija i ciljeva gospodarenja zasnovano na konzistentnom sustavu informacija o stanju i promjenama stanja šumskih resursa, kao i zahtjeva društva i vlasnika šuma (opće inventure, uređajne inventure, rezultati aktualnih znanstvenih istraživanja) učinkovito bi se raspodjeljivale i ispunjavale funkcije upravljanja, planiranja i nadzora gospodarenja šumama. S druge strane, dosljedna provedba propisanih postupaka gospodarenja kao rezultat neovisnog i objektivnog planiranja odvijala bi se uz odgovornu primjenu načela struke, pri čemu bi se dobit od gospodarenja šumama zasnivala isključivo na racionalizaciji radova i primjeni tržišnih načela. Radi kvalitetnije raščlambe šumsko gospodarskih ciljeva, smjernica i definiranja održivosti gospodarenja u prostornom smislu, ovakav model šumarstva može uključiti i raščlambu postojećeg jedinstvenog šumskogospodarskog područja na više područja koji su po svojim prirodnim obilježjima, povijesno-razvojnim značajkama i ekonomsko-demografskim posebnostima jedinstveni i međusobno se razlikuju (Smilaj 1957, Meštrović i dr. 1989, Bončina 2009, Čavlović 2013). Privatne šume bi se s obzirom na različitost njihove prostorne razdiobe dobro uklopile u takve prostorne jedinice strateškog i okvirnog planiranja gospodarenja šumama.

\section{ZAKLJUČCI}

\section{CONCLUSIONS}

Resursi privatnih šuma koji prema podacima ŠGOP i Nacionalne inventure sudjeluju u $24 \%$ površine i s $22 \%$ drvne zalihe svih suma nejednoliko raspodijeljene po prostoru Republike Hrvatske, s drvnom zalihom od $157 \mathrm{~m}^{3} /$ ha i značajnim udjelom gospodarski značajnih vrsta (hrastovi $26 \%$, bukva $20 \%$, bagrem $10 \%$, OTB $27 \%$ ) i koji se koriste na razini od oko polovice prirasta, predstavljaju značajan potencijal u pogledu proizvodnje drvnih i nedrvnih šumskih proizvoda. Proteklo razdoblje od 10-20 godina obilježeno je s obzirom na uređivanje privatnih šuma i aktiviranje gospodarenja velikom dinamičnošću, koja se može očekivati i u budućem razdoblju.

Neažurnost i nedovoljna sređenost katastra te izostanak potpunih baza podataka otežava pridobivanje informacija 
o obilježjima šumoposjeda i šumoposjednika i uzorkovanje za provedbu istraživanja. Nasuprot tomu, sustavna znanstvena istraživanja opće populacije (anketiranje) na nacionalnoj razini i usmjerena istraživanjem na užim razinama predstavljaju informacije koje ukazuju na obilježja šumovlasnika. Rezultati više provedenih anketiranja u značajnoj mjeri se podudaraju i ukazuju kako socio-demografska obilježja šumoposjednika značajno odstupaju od opće populacije u pogledu velike prosječne dobi i razmjerno niže razine obrazovanja šumoposjednika.

Prosječna obilježja ne smiju i ne trebaju biti temeljno polazište za oblikovanje strategija i smjernica unapređenja stanja i gospodarenja privatnim šumama, nego se pristupi trebaju zasnivati na postupnom i selektivnom usmjeravanju prema različitim skupinama šumoposjednika s obzirom na njihove sklonosti prema aktivnom gospodarenju. Uvažavanjem njihovih stavova, poticanjem upisivanja u Upisnik, poticanjem na gospodarenje i okrupnjivanje posjeda te poticanjem tržišne ekonomije, moguće je osigurati postupno unaprjeđenje gospodarenja privatnim šumama. Pri tome nije očekivano ni moguće u kratkom vremenu uspostaviti stručno utemeljeno i održivo gospodarenje u svim privatnim šumama, gdje izostanak gospodarenja neće bitno ugroziti šume, dok će posljedični gubici zajednice i šumovlasnika biti dodatni poticaj za gospodarenjem.

Ključna pretpostavka još učinkovitijeg ostvarivanja pomaka unapređenja gospodarenja privatnim šumama na operativnoj razini i razini pojedinih šumoposjeda je ustrojavanje jedinstvene javne šumarske službe koja bi objedinjavala funkcije upravljanja, planiranja i nadzora gospodarenja svim šumama na strateškoj, taktičnim i operativnim razinama planiranja održivog razvoja i gospodarenja šumama. Stalno educiranje svih dionika, od šumarskih stručnjaka do vlasnika šuma, te primjena aktualnih znanstvenih istraživanja trebaju biti sastavni dio tog novog sustava.

\section{ZAHVALA}

\section{ACKNOWLEDGMENTS}

Članak je realiziran u sklopu projekta: „Planiranje gospodarenja privatnim šumama u Hrvatskoj s obzirom na obilježja šumoposjeda i gospodarske zahtjeve šumoposjednika" financiranog od Ministarstva poljoprivrede. Uz Ministarstvu poljoprivrede zahvaljujemo se Savjetodavnoj službi , Savezu udruga šumoposjednika i svim anketiranim šumoposjednicima.

\section{LITERATURA}

\section{REFERENCES}

- Avidbegović, M., N. Petrović, D. Nonić, S. Posavec, B. Marić, D. Vuletić, 2010: Spremnost privatnih šumoposjednika u Hr- vatskoj, Srbiji i Bosni i Hercegovini na suradnju pri izgradnji i održavanju šumskih cesta. Šumarski list 134(1-2): 55-64.

- Berta, A., V. Kušan, J. Križan, D. Stojsavljević, D. Hatić, 2017: Posjedovne i površinske značajke šuma šumoposjednika u Hrvatskoj prema regijama. Šumarski list 141(1-2): 57- 64.

- Boon, T.E., H. Meilby, 2007: Describing management attitudes to guide forest policy implementation. Small Scale For. 6(1): 79-92.

- Bončina A., 2009: Urejanje gozdov - upravljanje gozdnih ekosistemov. Univerza v Ljubljani, Biotehniška fakulteta Oddelek za gozdarstvo in obnovljive gozdne vire, Ljubljana, 359 str.

- Bončina, A., J. Čavlović, M. Curović, Z. Govedar, M. Klopčić, M. Medarević, 2014: A comparative analysis of recent changes in Dinaric uneven-aged forests of the NW Balkans. Forestry, 87: 71-84.

- Curman, M., S. Posavec, Š. Pezdevšek Malovrh, 2016: Willingness of Private Forest Owners to Supply Woody Biomass in Croatia. Small-Scale Forestry 15(4): 551-567.

- Čavlović, J., M. Božić, A. Bončina, 2006: Stand structure of an uneven-aged fir -beech forest with an irregular diameter structure: modeling the development of the Belevine forest, Croatia. Eur. J. For. Res. 125(4): 325-333.

- Čavlović, J., 2010: Prva nacionalna inventura šuma Republike Hrvatske. Ministarstvo regionalnog razvoja šumarstva i vodnog gospodarstva, Zagreb.

- Čavlović, J., 2013: Osnove uređivanja šuma. Šumarski fakultet Sveučilišta u Zagrebu, Zagreb.

- Čavlović J., 2004: Unapređenje stanja i gospodarenja privatnim šumama na području Zagrebačke županije (znanstvena studija). Šumarski fakultet Sveučilišta u Zagrebu, Zagreb.

- Dubravac, T., Vuletić, D., Pernek, M., Liović, B., Novotny, V., Paladinić, E., Ahmetović, F., Dekanić, S., 2008. Informativni priručnik za šumoposjednike. MRRŠVG, Zagreb. 97 pp.

- Egan, A., S. Jones, 1995: The reliability of landowner survey responses to questions on forest ownership and harvesting. Northern J. Appl. For. 12: 184-186.

- Eggers, J., T. Lämås, T. Lind, K. Öhman, 2014: Factors Influencing the Choice of Management Strategy among Small-Scale Private Forest Owners in Sweden. Forests (5): 1695-1716.

- Ficko, A., A. Bončina, 2014: Ensuring the validity of private forest owner typologies by controlling for response style bias and the robustness of statistical methods. Scandinavian Journal of Forest Research 29(1): 210-223.

- Ficko, A., G. Lidestav, A. Ní Dhubháin, H. Karppinen, I. Zivojinovic, K. Westing, 2017: European private forest owner typologies: A review of methods and use. Forest Policy and Economics (in Press).

- Glück, P., M. Avdibegović, A. Čabaravdić, D. Nonić, N. Petrović, S. Posavec, M. Stojanovska, S. Imočanin, S. Krajter, N. Lozanovska, B. Marić, V. Milijić, A. Mrkobrada, S. Trninić, 2011: Private forest owners in the Western Balkans- Ready for the formation of interest associations, Research report 25, Project: Research into the Organizations of private forest owners associations in the Western Balkan region (PRIFORT), EFI.

- Halder, P., E. Paladinić, M. Stevanov, S. Orlović, T.J. Hokkanen, P. Pelkonen, 2014: Energy wood production from private forests - nonindustrial private forest owners' perceptions and attitudes in Croatia and Serbia. Renewable and Sustainable Energy Reviews 35: 515-526. 
- Haugen, K., S. Karlsson, K. Westin, 2016: New Forest Owners: Change and Continuity in the Characteristics of Swedish Nonindustrial Private Forest Owners (NIPF Owners) 1990-2010. Small-scale Forestry 15:533-550.

- Ingemarson,F., A. Lindhagen, L. 2006: A typology of small-scale private forest owners in Sweden. Scandinavian Journal of Forest Research 21(3): 249-259.

- Karaman, I., 1989: Privredni život banske Hrvatske, Zagreb: Sveučilišna naklada Liber, 1989.

- Kovačić, Đ., 1997: Problematika gospodarenja šumama na kojima postoji pravo vlasništva (privatne šume) u Hrvatskoj. Šumarski list br. 5-6: 225-242, Zagreb Ministarstvo poljoprivrede, šumarstva i vodnog gospodarstva.

- Kurelac, M., Z. Ladić, 2005: Hrvatske zemlje početkom 17. stoljeća, Povijest Hrvata - Druga knjiga Od kraja 15. st. do kraja Prvog svjetskog rata. Zagreb, Školska knjiga.

- Lopez, J. L., J. Calzadilla, A. Villa, 2015: A Proposal: “Agro-Erasmus". Proceedings ICABR 2015: 10th International Conference on Applied Business Research: Madrid, SPAIN, SEP 14-18. Pages: 595-603.

- Meštrović, Š., B. Prpić, S. Matić, 1989: Šumskogospodarska područja u organizaciji šumarstva Hrvatske. Šum. list 9-10: 423-444.

- Meštrović, Š., 1995: Dvijestodvadeset i peta godišnjica zakonske uredbe o šumama. Šum. list 119(8-10): 145-158.

- Ní Dhubháin, Á., R. Cobanova, H. Karppinen, D. Mizaraite, E. Ritter, B. Slee, S. Wall, 2007: The Values and Objectives of Private Forest Owners and Their Influence on Forestry Behaviour: The Implications for Entrepreneurship. Small-scale Forestry 6(4): 347-357.

- Nielsen-Pincus, M., G. R. Ribe, R. B. Johnson, 2015: Spatially and socially segmenting private landowner motivations, properties, and management: A typology for the wildland urbaninterface. Landscape and Urban Planning 137: 1-12.

- Krajter Ostoić, S., Posavec, S., Paladinić, E., Županić, M., Beljan, K., Curman, M., Ćaleta, M., Šimunović, N. 2015: Forest Land Ownership Change in Croatia. COST Action FP1201 FACESMAP Country Report, European Forest Institute Central-East and South-East European Regional Office, Vienna. 40 pages. Online publication"
- Paladinić, E., D. Vuletić, S. Posavec, 2008: Pregled stanja privatnog šumoposjeda u Republici Hrvatskoj. Rad. - šumar. inst. Jastrebar. 43(1): 45-58.

- Pleše, B., 2008: Kroz povijest šumarstva - u bolju budućnost. Hrvatske šume d.o.o. Zagreb, str. 141.

- Posavec, S., M. Avidbegoović, Dž. Bećirović, N. Petrović, M. Stojanovska, D. Marčeta, Š. Pezdevšek Malovrh, 2015: Private forest owners' willingness to supply woody biomass in selected South-Eastern European countries. Biomass and Bioenergy (81): 144-153.

- Posavec, S., M. Šašek, K. Beljan, 2011: The structure and potential of small scale forests in the north-west of Croatia. IUFRO SMALL-SCALE FORESTRY CONFERENCE, Freiburg, p 107112.

- Posavec, S., K. Beljan, 2012: Information analysis of management goals of private forest owners in Croatia. Informatol 45(3): 238-245.

- POUŠ 2015 - Pravilnik o uređivanju šuma (NN 79/2015)

- POUŠ 2015 - Pravilnik o uređivanju šuma (NN 79/2006)

- POUŠP 2014 - Pravilnik o Upisniku šunoposjednika (NN 137/2014)

- Smilaj, I., 1957: Prostorno uređenje šuma NR Hrvatske. Šumarski list 81(6-8): 246-274.

- ŠGOP 2006 - Šumskogospodarska osnova Republike Hrvatske, 2006-2015, Hrvatske šume

- ŠGOP 2016 - Šumskogospodarska osnova Republike Hrvatske za razdoblje 2016. - 2025. -NACRT, Zagreb, 2016.

- Teslak K., Žunić M., Vedriš M., Čavlović J., 2017: Status and challenges of small-scale private forest management in actual ecological and social circumstances - Croatia case study; IUFRO 125th Anniversary Congress, 18 - 22 September 2017, Freiburg, Germany

- UOŠSS 2006 - Uredba o osnivanju Šumarske savjetodavne službe (NN 64/2006)

- USTAV-RH 2014 - Ustav Republike Hrvatske (NN 56/90, 135/97, 8/98, 113/00, 124/00, 28/01, 41/01, 55/01, 76/10, 85/10, $05 / 14)$

- ZOŠ - Zakon o šumama (NN 140/05, 82/06, 129/08, 80/10, 124/10, 25/12, 68/12, 148/13, 94/14)

- ZOŠ 2018 - Zakon o šumama -PRIJEDLOG

\section{SUMIMARY}

Forest management in Croatia traditionally has been dominantly concentrated and directed toward state owned forests, thus it characterized with continuity and consistency of forest management planning and performance of management treatments, as well as fulfillment of principles of sustainable management on all levels. On the contrary, due to historic circumstances, small share and scattered fragmented forest distribution private forests was significantly uncared for management until not long ago. Thus, aim of this paper is to analyze and to present actual characteristics of private forests, forest estate and forest owners, as well as management circumstances namely institutional and legislative framework in which it is exists.

Share of $24 \%$ according to area and growing stock of $156 \mathrm{~m}^{3} /$ ha with richness tree species and tree/ stand developmental stages indicate on valuable natural forest resource in Croatia. Although during last years has achieved particular progress, existing property-juridical and land-register questions, unsuitable institutional framework and adverse socio-demographic characteristics of forest owners (large 
share of old population, low level of education) load with further improvements of private forest management.

With absence of complete data base, results of researches and surveys are valuable information sources describing the private forest owner's characteristics. In consideration on obtained results of average characteristics of forest owners (average age of 60 years, low education level) are not satisfactory, strategy and guidelines making should be based on knowledge of private forest owners preferences and types, especially of that which are active and which are ready to be active in forest management. Thereby, there is need to segregate forest owners which manage their forests and offer forest products on market (recorded in Register) from forest owners which owns small forest parcels and more or less use their forests for their own needs.

Improvement of balanced and sustainable private forest management planing would be based on transformation of the existing parallel forest management planning system divided according to categories of forest property (state, private). By integration of all publc competences over forests within unique institution with establishment more forest management regions, would provide fullfilment of requirements of sustainable forest management and long-term public interests. An effective and comprehensive establishment of sustainable private forest management is based on adoptation of knowledge and private forest management particularities including actual results of relevant scientific researches, from the all copartners of the forest management system.

KEY WORDS: forest management planning, forest property plan, size structure of forest estates, forest owners 